\title{
IAMJ
}

INTERNATIONAL

AYURVEDIC

MEDICAL JOURNAL

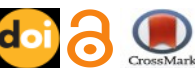

\section{AYURVEDIC MANAGEMENT OF DEVIATED NASAL SEPTUM - A CASE STUDY}

\author{
Indu Sharma ${ }^{1}$, Shamsa Fiaz ${ }^{2}$ \\ ${ }^{1}$ Assistant professor, Department of Shalakya Tantra, MJF Ayurvedic College, Rajasthan, India \\ ${ }^{2} \mathrm{HOD}$, Department of Shalakya Tantra, National Institute of Ayurveda, Rajasthan (302002), India
}

Corresponding Author: chinkisharma1@gmail.com

\section{https://doi.org/10.46607/iamj16p5032021}

(Published online: March 2021)

Open Access

(C) International Ayurvedic Medical Journal, India 2021

Article Received: 13/03/2021 - Peer Reviewed: 17/03/2021 - Accepted for Publication: 01/04/2021

\section{Check for updates}

\begin{abstract}
Nasa Pratinaha is one among the 31 Nasa Roga in which nasal obstruction is the main symptom. It is a commonly encountered disease in clinical practice. This disease occurs due to aggravation of Udan Vata, enveloped with Kapha, thereby causing obstruction in nose. In contemporary science this disease can be co-related with many disorders like turbinate hypertrophy, deviated nasal septum, nasal polyp, tumours, allergic rhinitis and others; among which deviated nasal septum is a common cause. Deviated Nasal Septum can be treated with surgical and medical methods. The medical and surgical managements have their own limitations, merits, and demerits like synechiae formation, rhinitis sicca, severe bleeding, septal perforation, septal heamatoma, septal abscess etc. In Ayurvedic classics the treatment for Nasa Pratinaha is Snehapana, Nasya, Dhoompana etc. The best drug prescribed in Nasa Pratinaha for Nasya is Bala Taila, the same oil is also recommended for Nasa Pichu. Thus, this study was carried out with the objective of to evaluate the effectiveness of Bala Taila Nasya and Nasa Pichu in the management of Deviated Nasal Septum. A case report of 43-year-old female who presented with complaints of frequent nasal obstruction, nasal discharge, discomfort in nose, and headache; was diagnosed with Deviated Nasal Septum. The patient was treated with Bala Taila Nasya and Nasa Pichu with the same oil. Hence Bala Taila administered as Nasya and Nasa Pichu was significant in controlling the symptoms of Nasa Pratinaha (Deviated Nasal septum) without recurrence in the follow up period.
\end{abstract}


Keywords: Deviated Nasal Septum, Nasa Pratinaha, Bala Taila, Nasya, Nasa Pichu

\section{INTRODUCTION}

Nasa Pratinaha is one among the 31 Nasa Roga in which nasal obstruction is the chief complaint and it is a commonly encountered disease in clinical practice. This disease occurs due to aggravation of Udan Vata, enveloped with Kapha, thereby causing obstruction in nose. In contemporary science this disease can be corelated with many disorders like turbinate hypertrophy, deviated nasal septum, nasal polyp, tumours etc. As Nasa Arshas and Nasa Arbuda are explained separately, it is appropriate to consider Nasa Pratinaha as deviated nasal septum and hence the same will be considered for this study.

Symptoms of Deviated Nasal Septum (DNS) are nasal obstruction in one or both nostrils, headache, epistaxis, middle ear infection etc and is usually asymptomatic in $80 \%$ of people. Its prevalence rate is $20-50 \%$ and associated with Allergic Rhinitis, Sinusitis, and Upper respiratory tract infections. It can occur in any age group and sex, but it is seen that males are more affected than females. Management of Deviated Nasal Septum in modern science is through medications such as nasal decongestants, antihistamines, nasal sprays and surgical procedure known as septoplasty. The symptoms usually reappear after the withdrawal of medication. Prolonged usage of antihistamines and nasal sprays are not recommended because which are cause unnecessary side effects like drowsiness, epistaxis, drying and crusting and the surgical approach has also failed to achieve desired results.

Therefore, an alternative solution in Ayurveda is sought which provides relief from all the symptoms of the disease as well as reducing the recurrent attacks. Snehapana, Nasya, Dhoompana etc are advised in Ayurveda classics for Nasa Pratinaha ${ }^{4}$. Nasya Karma is the best treatment for "Urdhavjatrugata Roga" as the quotation says "Nasa Hi Shirsoho Dwaram" which itself explains its importance. Nasya is also the best local route for administration of medicines to head which expel the deep seated Doshas and thereby removing the root cause and other deep-seated pathologies. The best drug prescribed in Nasa Pratinaha for Nasya is Bala Taila, which has to be administered in different forms. Also, it cures the associated Rhinitis which may be the precursor of this disease. The same oil is also recommended as Nasa Pichu, which is an important procedure employed in nasal blockage. The classical reference of Pichu is mentioned in Nasika Sandhana. (Keeping in view all these concepts a case study has been carried out to analyse the effect of Nasya and Nasa pichu with Bala Taila in Nasapratinaha.

\section{CASE REPORT}

A 43-year-old female presented with the complaints of frequent nasal obstruction, nasal discharge, discomfort in nose and headache since 3 years.

\section{On Examination}

On local examination, there was no external deformity and on Anterior rhinoscopy, there was slight deviation of nasal septum which is c-shaped towards right side with compensatory left sided inferior turbinate hypertrophy along with congested nasal mucosa. Routine haematology tests like Haemoglobin, Total Leukocyte Count, Differential Leukocyte Count, ESR and Absolute eosinophilic count investigations were done before the starting treatment. It was observed ESR and absolute eosinophil count were slightly increased but Haemoglobin, Total Leukocyte Count and Differential Leukocyte Count were within the normal limits.

\section{Ashtavidha Pariksha}

Nadi-76/min

Mutra, Malam, Jihwa, Shabda, Sparsha, Drik, Akrti all were normal.

\section{Past History}

Patient had taken medicines like antihistamines, decongestants, topical and systemic corticosteroids for 3 years; but not got any sustainable recovery.

As the disease was not manageable with above mentioned medical treatments and leading to complications like sleep apnoea and mouth breathing.

Thus, as per the principles of Nasapratinaha Chikitsha the patient was treated with Nasya and Nasa Pichu therapy which comprises of the following schedule. 
1. Poorva Karma - Snehana with Bala taila followed by Swedana until Samyak Swinna Lakshana appeared.

2. Pradhana Karma - Navana Nasya with 8 drops of Bala Taila into each nostril for 7 days and Nasa Pichu with Bala Taila for one hour in alternate nostrils with seven days gap in between two sittings.

3. Paschat Karma - Kavala dharana with rock salt dissolved lukewarm water. The patient was advised to avoid exposure to air, dust, smoke, etc., and also advised to take light diet.

\section{RESULT}

After one month of therapy there was significant improvement in the complaints related to Nasa Pratinaha. The complete reduction in the size of hypertrophied turbinate was observed along with nasal obstruction and all the other associated complaints like nasal discharge, discomfort in nose, and headache were completely reduced within two sitting. The investigations were repeated once again and there was normalcy in values of ESR and Absolute eosinophil count. After the follow-up period of one month, the patient had complete recovery from the disease symptoms such as nasal obstruction and other symptoms. There were no side effects observed during the treatment as well as after the completion of treatment.

\section{DISCUSSION}

The pathogenesis of Nasa pratinaha shows obstruction due to vitiated Vata and Kapha Dosha. As mentioned in Ayurveda, Nasya is the treatment of choice for all the disorders above the supra-clavicular region. It acts by removing all the morbid Doshas responsible for the disease and thus it removes the obstructive pathology of Nasa pratinaha and maintains normal functioning of the doshas. As prescribed in Ayurveda before the Nasya, patient should be treated with Snehana and Swedana because it is proved that application of heat and muscular exercise accelerates drug absorption through vascular path by increasing blood flow to the relevant area. The lying down postures which is prescribed for Navana Nasya Karma also play an important role; because head lowered position, fomentation and massage on the head etc. may have an impact on the neurovascular junction and drug absorption. The stimulation of olfactory nerve may affect neuro-endocrinal and neuro- psychological levels.

In Nasa Pichu the retention time of the drug is enhanced for better absorption as well as it may reduce the oedematous mucosal swelling and also help in dilating the constricted nasal passage. Local action of Pichu is based on cellular absorption of medicine which acts as Snehana and Lekhana; hence reduces mucosal oedema.

Bala Taila is having Vatahara properties and hence it shows action in Nasapratinaha. Bala Taila contains mainly Bala, Dashmula, Yava, Kol, Kulattha, Tila Taila, Godugdha and Madhura Gana Dravyas. Bala has Brimhana, Balya, Prajasthapana, Vatasanshamana, Nadibalya, Grahi, Raktapittashamaka, Jwaraghna, Ojhovardhaka, Vedanasthapaka, and Rasayana properties. Dashmula is Tridoshasamaka. Yavakolkulattha, Tila Taila and Godugdha have mainly Vatashasamaka properties. Due to these properties Bala Taila helps in pacifying the symptoms of deviated nasal septum.

\section{CONCLUSION}

This case study revealed that patient with Nasapratinaha (DNS) can gain significant relief in all the signs and symptoms such as nasal obstruction, discharges, headache through Ayurvedic management. The study concludes that this line of treatment enhances the speed of recovery with minimal risk and high patient acceptance in preference to other methods of treatment. This study can be done on larger samples to further verification of its statistical significance. Despite the limitations of this case study, the therapy may be an effective option in the treatment of Nasapratinaha (DNS) but further study should be carried out for large sample.

\section{REFERENCES}

1. Ashtanga Samgraha Uttara tantra 22/87, English translation by Prof. K. R. Srikantha Murthy, Vol III, $1^{\text {st }}$ edition, Chaukhambha Vishvabharati, Varanasi, 1997.

2. Dhingra P H and Shruti Dhingra, Diseases of Ear, Nose and Throat, $5^{\text {th }}$ edition, Elsevier, India, pp 164-165.

3. http://.webmd.com/allergies/deviated-septum,access date-05-03-2016. 
4. http://www.mayoclinic.com/health/deviatedsep-

tum/ds00977/dsection=treatments- and - drug, access date 05-03-2016

5. Sharma P V, Dravya Guna Vignnana, Vol II, Choukambha Bharati Academy, 2009

6. Susruts Samhitha, Uttara tantra 22/3-5, English translation by P V Sharma, Vol III, $1^{\text {st }}$ edition, Chaukhambha Vishvabharati, Varanasi, 2010, pp 251

7. Susruts Samhitha, Uttara tantra 23/3, English translation by P V Sharma, Vol III, $1^{\text {st }}$ edition, Chaukhambha Vishvabharati, Varanasi, 2010, pp 254-255

\section{Source of Support: Nil}

\section{Conflict of Interest: None Declared}

How to cite this URL: Indu Sharma \& Shamsa Fiaz: Ayurvedic Management of Deviated Nasal Septum - A Case Study. International Ayurvedic Medical Journal \{online\} 2021 \{cited March, 2021\} Available from: http://www.iamj.in/posts/images/upload/2864_2867.pdf 